\title{
Controversial Marketing Frontier Analysis and Future Prospect
}

\author{
Haihua Xie, Haiying Wei \\ Department of Marketing, Management School, Jinan University, Guangzhou, China \\ Email: 15820205797@163.com
}

How to cite this paper: Xie, H.H. and Wei, H.Y. (2018) Controversial Marketing Frontier Analysis and Future Prospect. Open Journal of Business and Management, 6, 470-477.

https://doi.org/10.4236/ojbm.2018.62035

Received: March 21, 2018

Accepted: April 27, 2018

Published: April 30, 2018

Copyright $\odot 2018$ by authors and Scientific Research Publishing Inc. This work is licensed under the Creative Commons Attribution International License (CC BY 4.0).

http://creativecommons.org/licenses/by/4.0/

\begin{abstract}
In the context of social media, the controversial marketing represents a new marketing strategy, but there is enough attention in the academic circles, and the understanding of the controversial marketing was blurred. According to the existing researches, we introduce the concept of controversial marketing and briefly describe that controversial topic is how to cause conversation.In order to apply controversial topics scientifically and promote the development of research in this field, we propose some research topics which are worthy to discuss in the future.
\end{abstract}

\section{Keywords}

Controversial, Controversy, Controversial Marketing, Topic Marketing, Conversation

\section{Introduction}

\section{1. Case One: "Song of the Phoenix"}

"Song of the Phoenix" is a film that promotes the older generation of Chinese artists and craftsmen. The director has died when the film is released, and the director is $\mathrm{Wu}$ Tianming, the leader of the fourth generation of Chinese directors. Because of the rarity of theatrical release at the time of release, its producer, Fang Li, kneeled down on a live broadcast platform and begged the theaters to increase the number of films, causing controversy among the people. On his kneeling, he succeeded in putting "Song of The Phoenix" at the top of the topic. According to a survey, the people who support him said it was the "most sincere" marketing in the interactive era, however, the other people who oppose him said it was a disguised moral kidnapping. His kneeling indeed promoted the slice rate which has already reduced to $1 \%$. "Song of The Phoenix" succeeded in 
getting people's attention. At the same time, it also caused people's discussion about the Chinese literary film market. "Song of The Phoenix" is at the condition of high reputation and low box office, in the commercial film wanly rolling over the environment, where is the way out? All these problems must be solved to present predicament of literary film [1].

\subsection{Case Two: "McDonald's Changed Its Name to Golden Arches"}

"Hey, where are you?" I'm in the golden arches. On October 12, 2017, McDonald's changed its name to golden arches. When this news released on the Internet, a lot of netizens teased and said, "Too hasty!" Maybe McDonald's didn't think that changing the name of the company can cause the strong reaction of the Internet users. While McDonald's responded immediately: this change is mainly about the aspect of business licenses, the daily business was not affected. McDonald's will sincerely service for consumers according to the food safety standards as before. However, many netizens still feel that the name was too local and they have been making fun of this in the Internet community. The netizens have enjoyed themselves while making fun of this. Yes, it was because the slots were so full and cheerful that the "golden arches" were thoroughly lit. The "golden arches" erupted again after the joke was fired. This round is mainly centered on the explanatory note. So many media find out all kinds of information and tell the big guy: haiah! This golden arch is an important symbol of McDonald's! It's history and culture! Don't just make fun of other people's dirt all day and learn from it! In addition, the passion of people has been activated. If McDonald's can be called golden arches, what is the name of KFC? What is Starbucks called? ...... Other brands have taken advantage of this incident. In a word, "golden arches" the three big words had been deeply embedded in the hearts of the Chinese people. Therefore, the event "McDonald's changed its name to golden arches" has become a very successful UGC (User Generated Content) mode promotion [2] [3] [4].

\subsection{Controversial Phenomenon}

Different advertisements, topics and brands are different in controversy. For example, American apparel brand Old Navy ads are less controversial than European fashion brands Benetton. Topics like weather are less controversial than abortion and gay marriage. Brands like Quaker Oats and Hallmark are less controversial than Marlboro and Walmart.

The general intuition is that more controversy, more likelihood to further discussion. Media executives believe that controversial TV shows are more likely to spark discussion (Steel 2011) [5], and public agencies use controversial advertising to get people involved in discussions about childhood obesity (Grinberg 2012) [6]. According to a market survey, when asked whether be willing to discuss a controversial topic, $91 \%$ of consumers think that controversial topic will increase the likelihood of people discuss the topic (Chen and Berger, 2013) [7]. 


\subsection{The Concept of Controversy}

Merriam-Webster (2003) broadly defined controversy as the concept that there are opposing views on a particular issue [8]. Controversial topics tend to be the issues that people are very passionate about (Boring 1929) [9]. For example, which kind of hand sanitizer is the most fragrant? Although there are a variety of opinions among people, it is unlikely that this will be a controversial topic, since most people are not so concerned about hand sanitizers. Like gay marriage, abortions, cell stem research, however, these topics are often thought to be more controversial, because people there are strong differences of opinion to the topic. Sometimes these views involve ethical issues.

Whether the topic is controversial or not depends on personal opinion. For example, fans may feel that a selected rookie is controversial, but non-fans don't think so. That is to say, there is some consensus in the cultural field, which topics are more controversial. Abortion is a controversial issue in the United States, but in Sweden it is less controversial (Ralston and Podrebarac 2008) [10].

\subsection{The Concept of Controversial Marketing}

The term "topic marketing" has recently become a buzzword in marketing. The term "topic marketing" on Google Trends shows that since June 2017 the number of searches for the word has increased linearly and the overall trend has been significantly higher (see Figure 1).

Although this data only represents the change trend of search volume, it also indicates that topic marketing is getting more and more attention. Wang (2013) found that at the level of online social network, marketers can deliberately create "viruses" and spread them on the Internet, allowing them to form "public topics" through the replication, transfer and diffusion of consumers [11]. Unfortunately, there is no specific investigation on the topic marketing application in China, and there is no corresponding academic research. In conclusion, people generally believe that the characteristics of the Web2. 0 can reveal the importance of "topic is king". Topic marketing which has huge market potential will play an increasingly important role in marketing, and even become a winning strategy of marketing. However, topic marketing is still a new concept in the academic field of marketing which lacks attention and in-depth research and the research in this field very fragmented, the boundary ambiguity, and causes the conceptual confusion. The most existing research are exploratory researches,

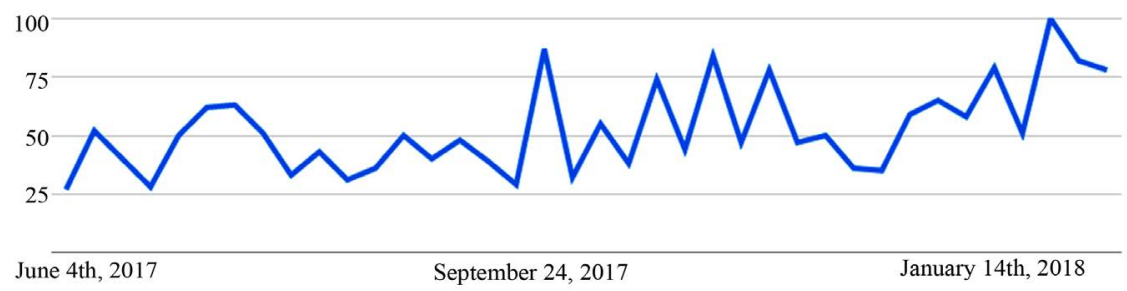

Figure 1. "Topic Marketing" the search trend chart. The Data Source: Google Trends, 2018. 
people attach importance to it is in enterprise marketing practice. It makes the such as content analysis, case analysis and industry investigation. Topic marketing mostly appears in the academic journals of news dissemination. It rarely mentioned this concept in marketing academic journals and let alone the research of empirical analysis.

The standard to judgment an event topic depends on whether the user can participate in the discussion of the topic, whether it is high correlation with users, and the subsequent events are expected by people. The process of the user discussing the topic is the process of propagation and fermentation of the event. If netizens opinion on a particular topic is one-sided, and this topic is often not too fire, even if the fire also won't last too long. If the other party has different opinions, and the two sides deadlocked, the subject itself will like "catfish effect", maintain the higher vitality for a long time. Therefore, the standard to judgment an event discussion depends on whether the topic controversial. Controversial marketing is a kind of topic marketing.

Therefore we suggest that through the media, controversial marketing makes the enterprise or brand related topics as the content which network users online talking about of, in order to expand enterprise or brand awareness for achieving the effect of marketing. Specifically, it is mainly based on the continuous creation of marketing value news events, brand construction activities and key product promotion activities. There mainly contain the brand, product, event, application, activity and etc in the topic content design. It spreads by many channels such as media, BBS, video sharing sites, blogs/weibo, search engines, SNS, etc.; Topics include news, comments, blog posts, BBS posts, topic discussions, microtext, video, Internet topics, and digital magazines.

Topic marketing in the form of controversy which can attract the attention of more people, is widely talked about and initiative to share by people. It naturally benefits the enterprise and brand related to this topic. With the continuous development of social media, controversial marketing are more and more taken seriously and used frequently by many enterprises, brands and individual. But why some enterprises, brands and people success? On the contrary some companies, brands, and individuals have failed? Therefore on the basis of the existing literature this article through the psychological mechanism of influencing people talking about controversial topic, summarize systematically the existing research results, and analyzes the main problems in controversial marketing research at present. At the same time this article discusses the future research direction, so as to provide reference for further research in this field.

\section{Controversy and Conversation}

\subsection{Controversy Affects People's Willingness to Talk}

Berger et al. (2013) first explored the psychological mechanism of controversy affecting people's willingness to talk through empirical analysis. Berger et al. (2013) was one of the first studies to apply the controversial factors to marketing 
[7].

\subsection{Controversial Topics Are More Interesting}

Esteemed biologist George C. Williams once observed that controversy make people feel biologically interesting (Roes 1998, 10) which has been proved [12]. There is no doubt that people are more likely to talk about interesting topics (Berger and Milkman 2012 [13]; Heath, Bell, and Sternberg 2001 [14]), people often talk about these topics in order to entertain themselves and others (Heath et al. 2001 [14]). Interesting topic is more entertaining. Talking about interesting topic is beneficial to self-enhancement. Just like the cars we drive or the clothes we wear, the things we say influence how others perceive us (Angelis et al. 2012 [15]; Berger and Milkman 2012 [13]; Wojnicki and Godes 2013 [16]). If people talk about interesting rather than boring topics people will think they are a very interesting person (Berger and Milkman 2012 [13]; Berger and Schwartz 2011 [17]).

Berger et al. (2013) think that controversy promotes interest, which thereby raised the possibility to be talked about [7]. Whether the identity of people is public and people will talk with others or not, interesting topic is still interesting.

\subsection{Controversial Topics Are Uncomfortable to Discuss}

People want to be accepted by society (Reiss 2004 [18]). They want to be integrated into society and be liked by others (Baumeister 1998 [19]; Goffman 1959 [20]). As a result, people's behavior in public places is often affected because they care too much about what others think (Argo, White, and Dahl 2006 [21]; Ratner and Kahn 2002 [22]). Controversial topics tend to cause differential and firm opinions. Some people have anti-abortion, and their neighbors may advocate abortion. Some people support tax reduction, and their friends' views may be the opposite. Most people think they are right and tend to ignore the advantages of opposing points of view (Boring 1929 [9]; Henle 1973 [23]). As a result, talking about controversial topics can lead to conflict in relationships. People may feel uncomfortable because they are afraid to suffer social exclusion (Buss 1990 [24]). Berger et al. (2013) believe that controversial topics can increase the discomfort and reduce the likelihood of being talked about [7].

\subsection{Anonymity Moderates the Relationship between Controversy and People's Willingness to Talk}

People often are anonymous on the Internet to discuss questions (Swidey 2010 [25]). Social critics have lamented that anonymity makes people say some unpleasant and dislike things. But people would not say these words when their identity is public (Perez-Pena 2010 [26]). When they are anonymous they would not such concern about social acceptance because there is no public "self" that they have to manage (Goffman 1959 [20]; Ratner and Kahn 2002 [22]). Berger et al. (2013) believe that when people are anonymous, discomfort should be a weak factor which drives people to talk [7]. 


\subsection{Relationship Closeness Moderates the Relationship between Controversy and People's Willingness to Talk}

However, not all identity-disclosed contexts are the same. When identity is disclosed, conversation partners are divided into people who are close to each other (friends) or those who are distant others (strangers). Due to a variety of factors, relationship closeness should moderate the fear of social acceptance (hence the role of discomfort).

First of all, if people close to us say something offensive, or we don't agree with them, it will not affect social acceptance, because one-off interaction is not likely to change our opinion about them. But for those with distant relationships, one-off interactions are crucial. Our opinion about a person is more dependent on one-off interactions, so people feel more uncomfortable when they talk about controversial topics.

Secondly, because we know people who are close to us, we will say something that is appropriate to ensure that the conversation goes smoothly. For example, when we know that our friends are anti-abortion, we know how to talk about promoting the legal idea of abortion. Therefore, it should be easier to raise a controversial topic among closely related people.

Finally, people usually are encouraged to maintain a close relationship (Baumeister and Leary 1995 [27]). When they find an interesting but also a controversial topic, it will give them freedom and security to bring up the topic, because they know that their friends will ignore the slight differences of opinion, and to solve these differences of opinion.

Therefore, Berger et al. (2013) believe that people should be comfortable with a controversial topic among people who are close to each other [7].

\section{Summary and Prospect}

In general, Berger et al. (2013) confirmed that by five studies (data from fields and laboratories), contrary to popular belief, the issue of controversy does not necessarily increase the willingness of people to talk about it [7]. A low degree of controversy can increase the willingness to talk about it, but more than a certain amount of controversy will weaken the willingness of people to talk about it. The relationship between controversy and the willingness to talk about it is driven by two mutually offsetting processes. Controversy increases people's willingness to talk by increasing their interest, but at the same time, it makes people uncomfortable, which tends to weaken people's willingness to talk. Situational factors such as anonymous, and whether people talk about with others, are affected by both roles of the intermediary variables to adjust the relationship between controversy and people's willingness to talk. Moreover, Berger et al. (2013) also found that, compared with the interest caused by controversy, the discomfort caused by controversy is a very weak factor, subject to specific situation and the people who is talk with [7].

Although controversial phenomenon and topic are so widespread in our life, 
and have been widely used in the marketing activity by a lot of enterprise and brand, people have been not strict to define various types of controversial topics in academia. There are not rigorous empirical analysis to the enterprise and brand to scientifically instruct how to effectively apply controversial topics. Moreover, controversial topics often touch on social norms, and how social norms influence people's willingness to participate in the discussion and sharing of controversial topics? Obviously, these are worth marketing scholars to explore deeply.

\section{References}

[1] http://www.sohu.com/a/122351572_355144

[2] http://news.cnfol.com/chanyejingji/20171026/25527284.shtml

[3] http://bj.news.163.com/17/1101/19/D269TD4304388CSA.html

[4] https://zhidao.baidu.com/question/1515595793671711500.html

[5] Steel, E. (2011) Buzz, Viewers Diverge. Wall Street Journal. http://online.wsj.com/article/SB10001424052970204517204577042471838562202.ht $\underline{\mathrm{ml}}$

[6] Grinberg, E. (2012) Georgia's Child Obesity Ads Aim to Create Movement out of Controversy.

http://www.cnn.com/2012/02/07/health/atlanta-child-obesity-ads/index.html

[7] Chen, Z. and Berger, J. (2013) When, Why, and How Controversy Causes Conversation. Social Science Electronic Publishing, 40, 580-593.

[8] Merriam-Webster (2003) Merriam-Webster's Collegiate Dictionary. http://www.merriam-webster.com/dictionary/controversy

[9] Boring, E.G. (1929) The Psychology of Controversy. Psychological Review, 36, 97-121. https://doi.org/10.1037/h0072273

[10] Ralston, M. and Podrebarac, E. (2008) Abortion Laws around the World. Pew Forum on Religion and Public Life. Pew Research Center. http://www.pewforum.org/Abortion/Abortion-Laws-Around-the-World.aspx

[11] Wang, C.Y. and Lei, L. (2013) Research on the Mechanism and Market Application of Electronic Word-of-Mouth Influence. Foreign Economics \& Management, 35, 62-71.

[12] Roes, F. (1998) A Conversation with George C. Williams Natural History, 107, 10-13.

[13] Berger, J. and Milkman, K.L. (2012) What Makes Online Content Viral? Journal of Marketing Research, 49, 192-205. https://doi.org/10.1509/jmr.10.0353

[14] Heath, C., Bell, C. and Sternberg, E. (2001) Emotional Selection in Memes: The Case of Urban Legends. Journal of Personality and Social Psychology, 81, 1028-1041. https://doi.org/10.1037/0022-3514.81.6.1028

[15] Angelis, M., Bonezzi, A., Peluso, A., Rucker, D. and Costabile, M. (2012) On Braggarts and Gossips: A Self-Enhancement Account of Word-of-Mouth Generation and Transmission. Journal of Marketing Research, 49, 551-563. https://doi.org/10.1509/jmr.11.0136

[16] Wojnicki, A.C. and Godes, D.B. (2013) Signaling Success: Strategically-Positive Word of Mouth. Working Paper, University of Toronto, Toronto.

[17] Berger, J. and Schwartz, E.M. (2011) What Drives Immediate and Ongoing Word of 
Mouth? Journal of Marketing Research, 48, 869-880. https://doi.org/10.1509/jmkr.48.5.869

[18] Reiss, S. (2004) Multifaceted Nature of Intrinsic Motivation: The Theory of 16 Basic Desires. Review of General Psychology, 8, 179-193. https://doi.org/10.1037/1089-2680.8.3.179

[19] Baumeister, R.F. (1998) The Self in The Handbook of Social Psychology. Vol. 1, McGraw-Hill, New York, 680-740.

[20] Goffman, E. (1959) The Presentation of Self in Everyday Life. Anchor, New York.

[21] Argo, J.J., White, K. and Dahl, D.W. (2006) Social Comparison Theory and Deception in the Interpersonal Exchange of Consumption Information. Journal of Consumer Research, 33, 99-108. https://doi.org/10.1086/504140

[22] Ratner, R.K. and Kahn, B.E. (2002) The Impact of Private versus Public Consumption on Variety-Seeking Behavior. Journal of Consumer Research, 27, 246-257. https://doi.org/10.1086/341574

[23] Henle, M. (1973) On Controversy and Its Resolution in Historical Conceptions of Psychology. Springer, New York, 47-59.

[24] Buss, D.M. (1990) The Evolution of Anxiety and Social Exclusion. Journal of Social and Clinical Psychology, 9, 196-201. https://doi.org/10.1521/jscp.1990.9.2.196

[25] Swidey, N. (2010) Inside the Mind of the Anonymous Online Poster. Boston Globe Sunday Magazine.

http://www.boston.com/bostonglobe/magazine/articles/2010/06/20/inside_the_min d_of_the_anonymous_online_poster/?pagepfull

[26] Perez-Pena, R. (2010) News Sites Rethink Anonymous Online Comments. New York Times, April 12, B1.

[27] Baumeister, R.F. and Leary, M.R. (1995) The Need to Belong: Desire for Interpersonal Attachments as a Fundamental Human Motivation. Psychological Bulletin, 117, 497-529. https://doi.org/10.1037/0033-2909.117.3.497 